\title{
What's the role of brand identity in creating value of the electricity sector? A dynamic model-based analysis
}

\author{
¿Cuál es el rol de la identidad de marca en la creación de valor \\ del sector eléctrico? Un análisis dinámico basado en modelos
}

\author{
Milton M. Herrera ${ }^{1}$ \\ Recibido 19 de abril de 2019, aceptado 7 de febrero de 2021 \\ Received: April 19, 2019 Accepted: February 7, 2021
}

\begin{abstract}
The rapid growth of the renewable energy market has provoked pressing challenges because of the significant financial resources required, highlighting the need for marketing of the electricity sector. The role of brand identity influences on customer image that affects demand changes and financial resources used by SMEs in the electricity sector. This paper presents a dynamic model-based analysis to understand better the role of brand identity in creating value in SMEs. The simulation model aims to assess alternative strategies of brand identity to support SMEs in the electricity sector to promote efficiently value creation. Simulation results show that the high customer value perception allows aligning the electricity utility industry to create more value. This dynamic perspective presents a new point of view that contributes to managers and policymakers in analysing the relationships of stakeholders. Thus, the paper will give some insights on the design of an alternative business model based on non-conventional renewable energy.
\end{abstract}

Keywords: Electricity sector, solar power, simulation, value creation, SMEs, electricity utilities.

\section{RESUMEN}

El rápido crecimiento del mercado de energía renovable ha provocado serios desafíos debido a los importantes recursos financieros que se requieren, destacando la necesidad de comercialización del sector eléctrico. El rol de la identidad de marca influye sobre la imagen del cliente que afecta los cambios de la demanda y los recursos financieros utilizados por las pequeñas y medianas empresas (PYMES) en el sector eléctrico. Este artículo presenta un análisis basado en un modelo dinámico para entender mejor el papel de la identidad de marca en la creación de valor in las PYMES. El modelo de simulación está orientado a evaluar alternativas estratégicas de la identidad de marca para soportar las PYMES en el sector eléctrico, para promover eficientemente la creación de valor. Los resultados de simulación mиestran que la alta percepción de valor del cliente permite alinear la industria para crear más valor. Esta perspectiva dinámica presenta un nuevo punto de vista que contribuye a los gerentes y formuladores de política en el análisis de las relaciones de las partes interesadas. Por lo tanto, el artículo ofrecerá algunas perspectivas sobre el diseño de un modelo de negocio alternativo basado en energía renovable no convencional.

Palabras clave: Sector eléctrico, energía solar, simulación, creación de valor, PYMES, servicios de electricidad.

\footnotetext{
1 Universidad Militar Nueva Granada. Economic Sciences Research Centre. Bogotá, Colombia. E-mail: milton.herrera@unimilitar.edu.co

* Corresponding author: milton.herrera@unimilitar.edu.co
} 


\section{INTRODUCTION}

Considering that now customers are best informed and more demanding, it is a priority to give more value and consider the stakeholders [1-4]. Indeed, it becomes much more relevant when considering how the marketing process differs across utility industries [5]. For instance, the generators and distributors will tend to have different marketing dynamics related to customer perception. Given that customer perception contributes to industry and commercial development [5-8], the role of value perception influences customers, which affects financial resources used by the electricity utility industry.

The creation of customer value comprises a process where customers evaluate the benefits received and the sacrifices given form using a product/service. Early marketing studies focused on product quality as the primary "get" component and product as the main "give" component [9]. When a consumer uses a product or service, they know that have to pay something to receive what they need. At this point, the value becomes relevant to satisfy a need causing a very good impression because the customer evaluates the benefits according to their experiences.

This process of creating value involves some drivers that determine the nature of the relationship between the firm and the customer, which helps estimate the level of profitability and the lifetime of each customer value [10]. As a result, the firm has to determine the drivers; these drivers impact the overall perceptions of the stakeholders. The value drivers could classify into two types: exchange characteristics and customer heterogeneity [10]. Exchange characteristics encompass the set of variables that define and describe relationship activities in the broadest sense. Customer heterogeneity refers to the demographic and psychographic indicators that help a firm in segmenting customers and managing customer-firm relationships. This perspective analyses the customer as an individual with an specific personality, likes, interests, and belongs to a specific segment. Additionally, it is helpful to differentiate three levels of customer value: (1) the expected level; (2) the desired level; and (3) the unanticipated level [11]. These levels allow studying the customer perception from several scenarios depending on the state of the purchase.

The management literature on value is clustered generally around three categories of value: financial economists advocate shareholder value, marketers advance customer value, and stakeholder theorists promote stakeholder value [12]. If companies apply these categories to implement new tactics is possible to have a better understanding of the consumer needs.

Studies previously have examined attitudes and behaviour towards tangible green products; however, few studies have examined these factors that apply to intangibles renewable power services [5, 13, 14], particularly in SMEs. The SMEs in the electricity sector requires a deep understanding of the behaviour dynamic of intangibles resources, such as brand identity and its implications on value creation. For this reason, the challenge is to help the customer perceive total value than the total cost of acquisition and usage [6] through the design of marketing policies based on brand identity. It is essential to evaluate the impact that brand might have on the dynamic performance of SMEs in the electricity sector. Dynamic performance analysis of SMEs is needed to be able to propose a marketing policy both suitable and sustainable to foster consumer education on renewable energy advantages. In this sense, the brands can provide products with symbolic meaning that contribute to improving customers' perception.

Despite the importance of brand identity to the marketing literature and marketing practice $[5,15$, 16], there is a pressing need for further understanding of how value should be measured [17]. Value measures can be expressed in terms of outcomes and related drivers. This relation is aimed by a dynamic behaviour of strategic resources of the utility industry. In response to this gap in the literature, this paper proposes a performance management perspective based on simulation modelling.

An important complexity factor in the utility industry is related to the wide range of stakeholders who play an important role in the marketing policy. Regulatory agencies, the business community, and consumer protection agencies take part in the implementation of these decisions $[8,18]$. This increases the effort 
of marketers and managers to foster creating value process. Thus, this paper provides a model-based framework for analysing creating value process and offers guidance for designing alternative marketing policy formulations for stakeholders of the energy supply chain.

One of the fastest-growing products for the electricity industry is rooftop solar panel of greater use in the residential sector. In the case of Colombia, the potential of solar energy is very high; solar radiation reaches a daily average of $4.5 \mathrm{kWh} / \mathrm{m}^{2}$, which exceed the average world daily of $3.9 \mathrm{kWh} /$ $\mathrm{m}^{2}$ [19]. Although solar power has great potential in the household sector and positive impacts on emission reduction [20,21], Colombia has not developed a residential market sufficiently, which not allow rapid response to the challenges of the household market. In this context, the SMEs of the electricity sector play an important role in industry and commercial development. Thus, the image of SMEs in the electricity sector influence citizens' perception and allows appropriating technologies innovation related to non-conventional renewable energy, such as solar power.

The behavioural patterns of customers generated by the dynamic of the Latin-American electricity market required a systematic analysis [22-24]. Particularly, system dynamics is a methodology of simulation based on feedback structures analysis and time-delays, which define the behaviour of a complex social system [25-28]. Developing an intuitive understanding of dynamics is also challenging for policymakers and managers. In this context, the paper analyses the effects of brand identity, image, financial resources and customer's behaviour on SMEs in the electricity sector as from future scenarios generated by different marketing policies through the simulation modelling.

This paper discusses the literature, including brand identity and its implications on SMEs, in the following sections. Next, it presents a description of the methodology of simulation used. This section considers the validation model and assumptions data in the case of a study for SMEs in the photovoltaic industry of Colombia. Additionally, to this, the following section presents data and results obtained by a simulation model. The paper concludes with findings and implications for policymakers and managers.

\section{THE BRAND IDENTITY AND ITS IMPLICATIONS ON SMES OF ELECTRICITY SECTOR}

Brand identity is a key concept in brand management, as it not only defines the purpose and meaning of the brand, and the directions to follow, includes a set of characteristics and dimensions that determine the brand's way of being, the thinking and behaviour [29]. Some of the most important brand identity definitions highlight the relationships between customer, brand and stakeholders [30-32]. Another conceptual framework defines twelve dimensions organised around four perspectives - product, persons, organisation and symbol [33].

Brand identity has been shown to play an important role in consumer behaviour [8, 34]. It is an essential basis required to compete effectively and succeed in a service context [31]. Energy is traditionally seen as a service in which features are not perceived differentiators [5], hence the importance of SMEs' on creating an identity with the service they offer, creating a difference in the market.

Although the SME market is booming, these SMEs face difficulties in staying in a constantly evolving market. To grow continuously in the energy sector, companies must understand the importance of creating value in improving their performance in the market. It has been discovered that the lack of implementation of value creation acts as a barrier for these SMEs. In addition, it is identified that SMEs have problems establishing a strong brand image through the creation of value [35].

SMEs engaged in the commercialization of energy must understand that the generation of energy from renewable sources is beginning to gather strength worldwide, motivating leaders to implement policies aimed at increasing the number of projects in this field, so therefore, they must look for ways to strengthen their brand in this promising market. Latin America is no stranger to this and has already developed many projects to produce electricity through renewable sources, although to a large extent, with multilateral donor agencies' support [36]. However, existing projects are insufficient and have often been the result of efforts made by foreign organizations and not at the initiative of Latin American governments [37]. 
The global photovoltaic market has experienced impressive growth in the installation during the last decade, with an average annual growth rate of more than $50 \%$ due to the support of government policy and other financial incentives that encourage its installation [38, 39]. Additionally, in some Latino American countries, the photovoltaic industry is expanding rapidly because of lower generation costs for large-scale photovoltaic systems [40]. Although the development of energy photovoltaic in Latin America is at a disadvantage compared to other countries [41-43], Latin American countries differ from other countries because of their energy and climate characteristics, including a combination of highly renewable energies and very high renewable energy potentials, together with high rates of deforestation and degradation that require regional responses to regional problems [44]. This becomes a great opportunity for SMEs since these characteristics are the main added values that must identify them and start creating value for their brands in the national market. In this sense, some measures that may foster demand for green electricity in a liberalised market structure include marketing, branding and labelling schemes for green electricity $[34,45]$.

Despite the relevance of brand identity management for SMEs, few research explores this strategic resource $[29,46]$. This issue is especially important in the services sector because of its implications on the dynamic performance of SMEs in terms of financial resources $[47,48]$. The dynamic performance management (DPM) perspective allows understanding the effects and relations between the strategic resources, performance drivers and endresults of SMEs. Thus, this paper shows a perspective to decision-makers to understand how the policy's critical performance factors can be affected and how strategic resources with the end-results can be related, as illustrated in Figure 1. Despite that price is generally seen as an important component in the purchase [5, 49], others aspects like the image and customer perception should be taken into account.

Although brand identity definitions highlight that brands should maintain their identity, others suggest that brand identity as a dynamic concept $[4,29$, 34]. Several brand identity scholars have noted the importance of brands developing customer relationships [50-53]. Brand identity precedes and represents an organization image's and reputation, which influence customer behaviour of [54-56]. Thus, A dynamic behaviour of brand identity has several implications on the performance of SMEs [57].

In general, companies must understand the importance of brand identity for SMEs and their stakeholders. The current businesses model is aimed at creating value through brand identity. The purpose of a sustainable business is, first, to create value for customers and, second, to extract some of that customer value in the form of profit, thereby creating value for the firm [10]. The value identification of customers and stakeholders determines a business strategy [58], which allows a competitiveness advantage for SMEs [59, 60]. Table 1 shows the values and stakeholders proposed for the energy supply chain.

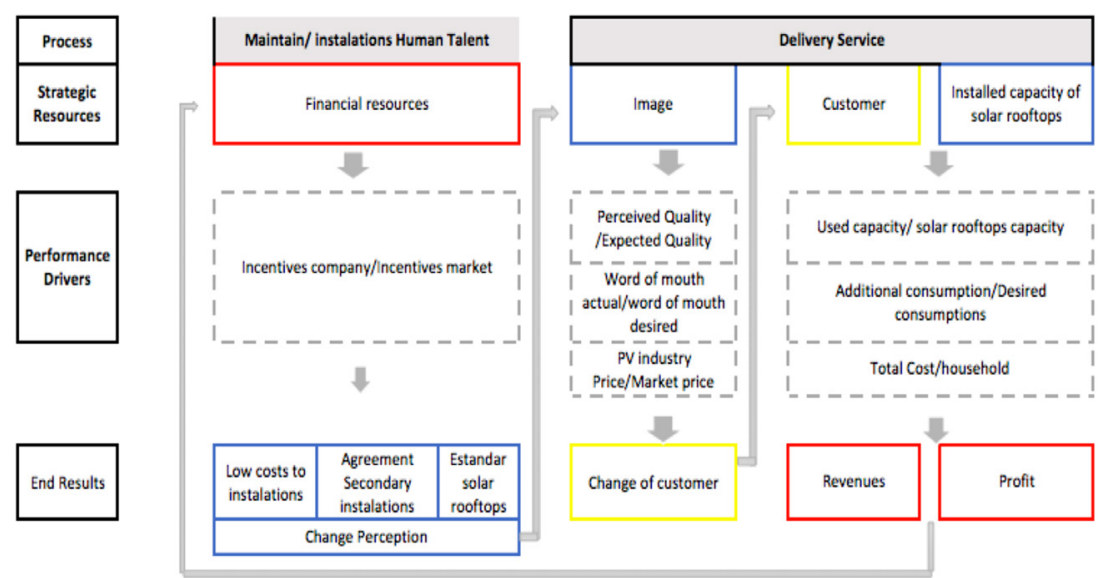

Figure 1. DPM chart showing effects of image perception on financial resources. 
In this context, the simulation could help in the process of prediction and prospective becoming a tool to improve the perceptions and probably other aspects related to customer satisfaction and brand identity. The following section present the methodological approach used.

\section{METHODOLOGICAL APPROACH}

Forrester first developed the modelling and simulation method of system dynamics in the 1950s to analyse complex behaviours in social sciences and management [61].

The characteristic of system dynamics makes it extremely useful when involving complex issues and intangible resources that interacted in the long term. In this case, customers' brand identity and perception are intangible resources that affect SMEs' performance and competitiveness [60].

The steps to simulate a system dynamics model are illustrated as follows [25, 62-64]:

a) Identify and describe the problem through a dynamic hypothesis (systemic structure). b) Create a simulation structure from stock and flow diagram, which involve a mathematical model based on differential equations.

c) Define the data of the simulation model.

d) Validate and analyse the policy through simulation scenarios.

e) Results.

The modelling process with system dynamics is an iterative and continuous process of hypothesis formulation, validation and formal model revision that represents the system studied $[25,65]$.

Simulation modelling can provide an interesting idea about the most important variables related to brand identity and how they interact in value creation. In this sense, this paper presents a similar model to proposed by others studies with the system dynamics methodology $[48,60,63,66]$.

\section{Dynamic hypothesis}

This paper represents the dynamic hypothesis through a causal loop diagram (CLD), as illustrated in Figure 2. CLD links system variables by arrows, which show the direction of effect influence: positive for direct and negative, for an inverse influence, to

Table 1. Stak eholders and values of the energy supply chain.

\begin{tabular}{|c|c|c|c|c|}
\hline Stakeholders & Suppliers & Industry & Distribution & Demand \\
\hline Values & $\begin{array}{l}\text { - Government policy } \\
\text { - Location selection } \\
\text { - Land usage } \\
\text { - Sustainability }\end{array}$ & $\begin{array}{l}\text { - Conversion efficiency } \\
\text { - Stability supplement } \\
\text { - Cost reduction } \\
\text { - Less environmental impact } \\
\text { - Full cell technology }\end{array}$ & $\begin{array}{l}\text { - Distribution efficiency } \\
\text { - Balance in demand } \\
\text { - Storage } \\
\text { - Distributed grid }\end{array}$ & $\begin{array}{l}\text { - Emission pollution } \\
\text { - Employment } \\
\text { - Education } \\
\text { - Continuous supply }\end{array}$ \\
\hline
\end{tabular}

Source: [58].

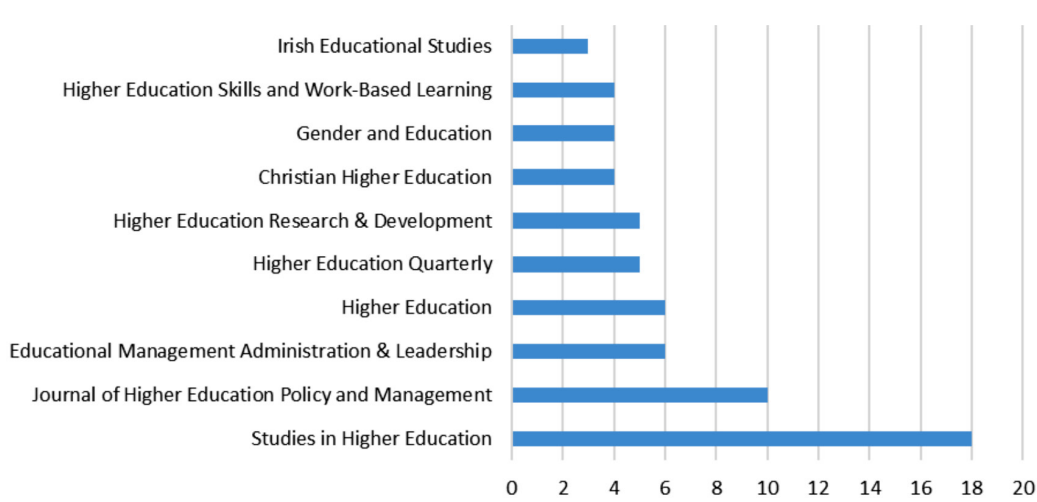

Figure 2. CLD of relationships between SMEs resources, brand identity and value creation. 
analyse the dynamics of change in value creation, brand identity and SMEs resources [61].

This diagram describes the influences and interactional relationships among variables affecting the value creation in SMEs and their resources. Broadly, this hypothesis indicates that the changes in resources affect the brand identity according to the investment strategy. Also, these changes generate an impact on creating value.

Loops B1 and B2 represent the investment of SMEs resources and demand balancing, respectively. In the case of loop B1, the profit margin is calculated as the division between SMEs resources and accumulated customers, which involve an impact on price. The price changes affect the investment in SMEs resources. This involves changes in the brand identity that generate customer value, creating the reinforcing loop R1.

\section{MODEL DESCRIPTION}

To develop a quantitative model from qualitative CLD, four building elements are used: stock, flow and auxiliary, as presented in Table 2 .

This research developed a stock and flow diagram, as illustrated in Figure 3, to analyse decisionmaking in SMEs. To analyse decision-making in

Table 2. Basic building elements used in system dynamics.

\begin{tabular}{|l|c|l|}
\hline \multicolumn{1}{|c|}{ Elements } & \multicolumn{1}{|c|}{ Symbol } & \multicolumn{1}{c|}{ Description } \\
\hline $\begin{array}{l}\text { Stock (level) } \\
\text { Flow (rate) } \\
\text { Auxiliary (converter) }\end{array}$ & $\begin{array}{l}\text { This variable describes the condition or state of } \\
\text { the system at any particular time. }\end{array}$ \\
$\begin{array}{l}\text { Alters stock level by an inflow or an outflow. } \\
\text { It holds the values for constants, defines external } \\
\text { inputs to the model, calculates algebraic relationships } \\
\text { and defines graphical functions. }\end{array}$ \\
\hline
\end{tabular}

Sources: [61, 65, 67].

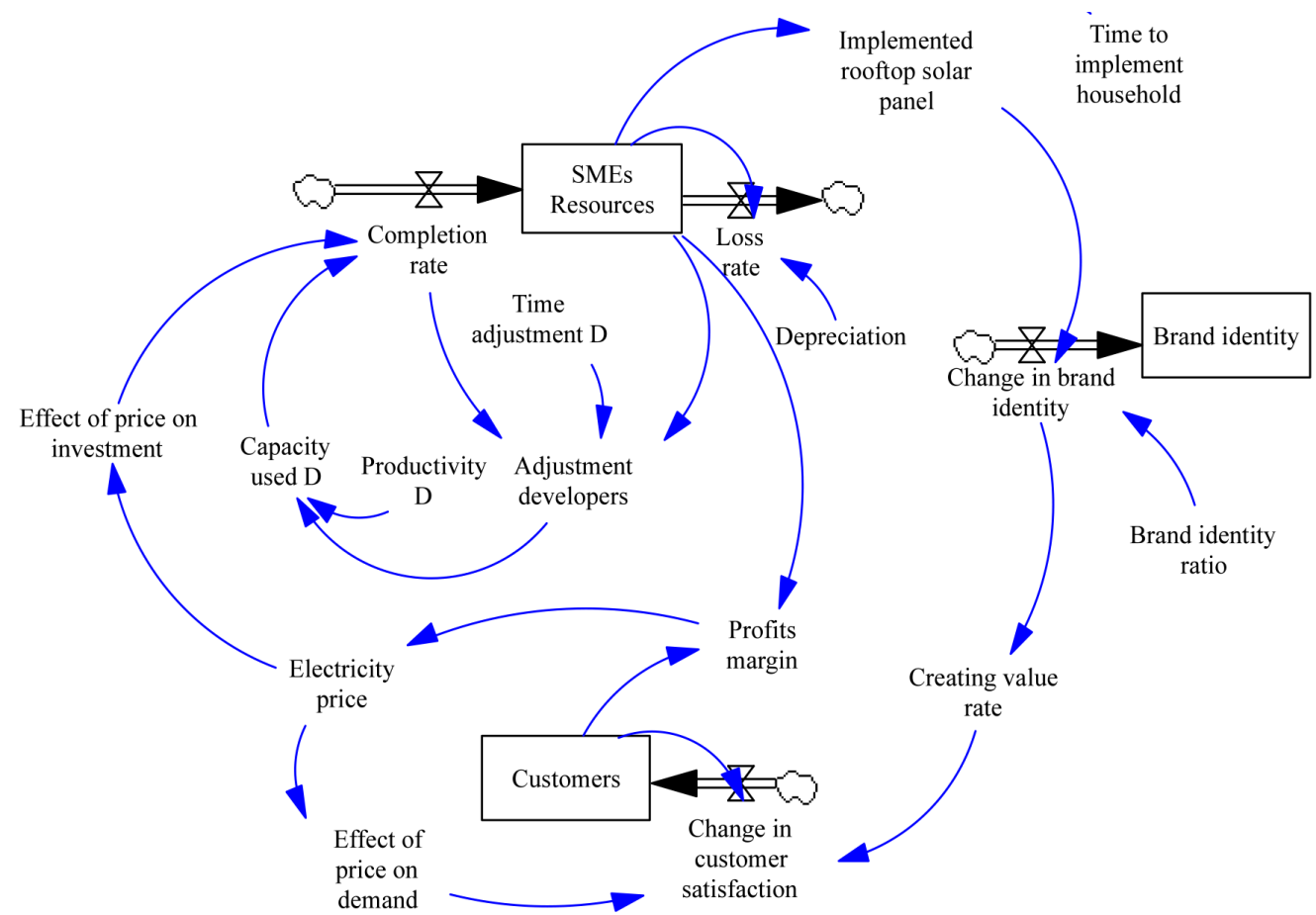

Figure 3. Stock-and-flow diagram of brand identity effect on SMEs resources and customers. 
the SMEs, this research developed a stock and flow diagram, as illustrated in Figure 3. The stock and flow diagram structure replicates the dynamic behaviour of the SMEs resources, customers and brand identity used by the simulation model. This diagram represents the relations between SMEs resources used, change in brand identity and its effect on customer satisfaction. The profits margin is the result of the division between SMEs resources and accumulated customers. The time to implement rooftop solar panel in the household is a performance driver that affects service perception, which involves a change in brand identity. This change influences value creation in SMEs.

The main aspects that oriented the decision-making are strategic resources (SMEs resources, customer and brand identity), performance drivers (profits margin and time to implemented rooftop solar panel) and end results (change in customer satisfaction and change in brand identity), as illustrated in Figure 4.

\section{Mathematical model}

The degree to which the SMEs use their resources is characterized by changes in production capacity, which accumulated. Thus, the SMEs resources
(SMEr) were estimated as from initial resources $\left(I R_{0}\right)$ and the difference between the inflow and outflow, namely start rates (Sr) and finish (Fr) of production, as illustrated in Equation (1).

$$
\operatorname{SMEr}(t)=I R_{0}+\int(\operatorname{Sr}(t)-\operatorname{Fr}(t) \cdot d t[\text { Units }])
$$

The response capacity of SMEs resources is determined by the adjustment between current capacities and desired. For instance, the adjustment of developers (AD) was calculated taking, into account the used resources of SMEs (DCI) developers' capacity (DC) and the time to adjust capacity (TAC), as shown in Equation (2).

$$
A D=(D C I-D C) / T A C[\text { Units / year }]
$$

The simulation model also estimated the expected customers through an inflow called a change in customer's satisfaction (Cr). Accordingly, the expected customers (EC) are defined as shown in Equation 3:

$$
E C(t)=E C_{0}+\int(C r(t)) \cdot d t[\text { Units }]
$$

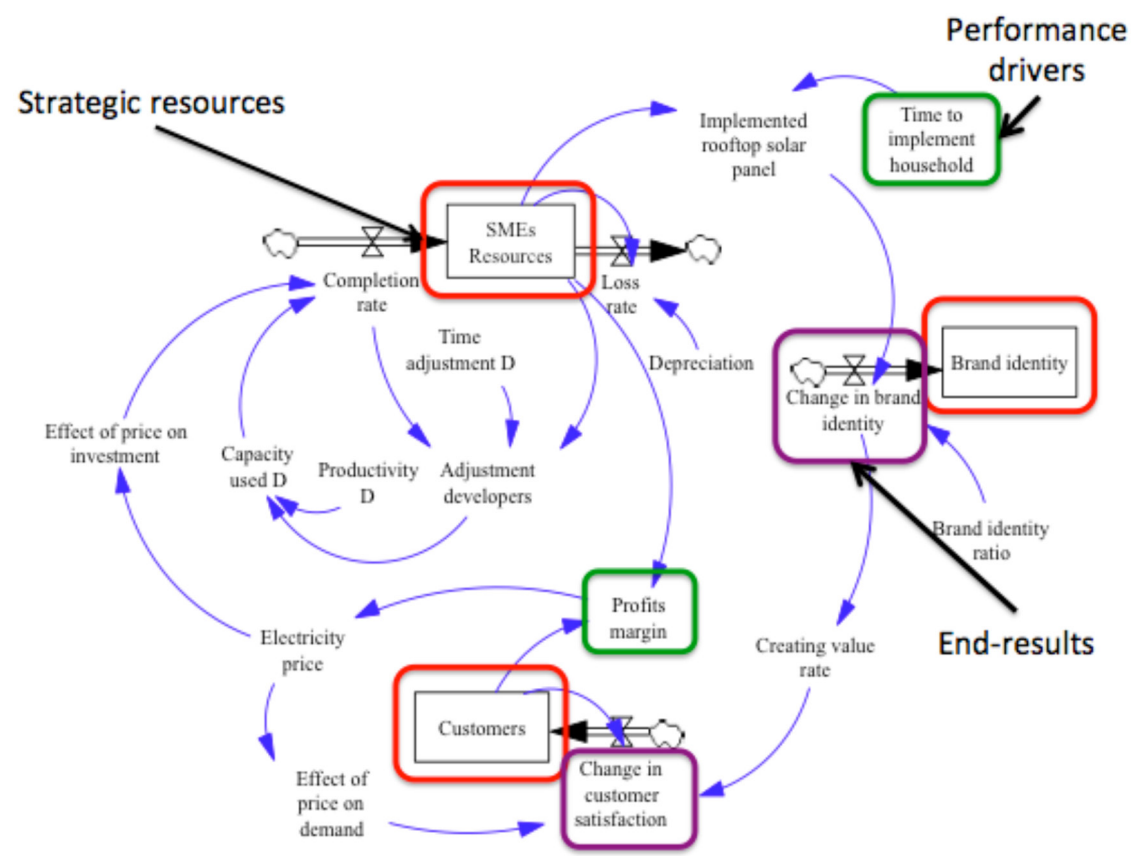

Figure 4. Relationships between strategic resources, performance drivers and end results for the SMEs. 


\section{Validation model}

To simulate the mid- to long- term effects of response time, a simulation time horizon of 13 years was considered. Also, the simulation model was tested and validated as an interactive process [67-70]. The model employed time series of the installed capacity projection of rooftop solar panel obtained by [71] to validate and evaluate the dynamic behaviour. The mean squared error (MSE) is a measure of the average squared difference between the estimator and outcomes. The Theil inequality statistic provides a measure of the MSE in the predicted values of simulation through the components of the mean $\left(\mathrm{U}^{\mathrm{M}}\right)$, variance $\left(\mathrm{U}^{\mathrm{S}}\right)$, and covariance $\left(\mathrm{U}^{\mathrm{C}}\right)$. The error decomposition analysis for the variables implemented rooftop solar panel, and accumulated customers are presented in Table 3. Results show that error has a little trend variation, so it is unsystematic. Thus, the fit between model and history is suitable for marketing policy analysis.

\section{ANALYSIS OF ALTERNATIVE MARKETING POLICY}

In essence, the system dynamics methodology model and simulate the market structure to design management strategies to improve the performance of SMEs in the electricity sector. In this context, scenarios based on simulation can provide guidelines for policy planning and management of complex and dynamic system $[72,73]$. The analysis of the changes in the brand identity ratio and implemented rooftop solar panel provide important elements to evaluating alternatives marketing policy for SMEs in the electricity sector in Colombia. Table 4 shows the proposed design of four scenarios to evaluate the decisions (marketing policy) take by marketers of two SMEs in this sector. These scenarios are the result of the combination of two conditions associated with changes in brand identity and implemented rooftop solar panel that affect the value creation in SMEs resources. The first scenario represents delays in the implementation of rooftop solar panel in the household (IRSP). Also, this scenario represents a lower brand identity ratio for SMEs. The second scenario benefits the development of brand identity and limits the growth of the implementation of rooftop solar panel, while the third scenario is quite the opposite. The final scenario is coordinated marketing policy and appropriates between both times to implement the rooftop solar panel (Tim) and brand identity ratio (BIR), which reaches through the mathematical relation proposed by Equation 4 .

$$
I R S P={ }^{S M E r} / \text { Tim*BIR }
$$

Scenario 4 is given as the process by which stakeholders adopt a high level of identity that contributes to improving the SMEs' use. Simulation scenarios 1, 2 and 3 are characterised by lower

Table 3. Error analysis of the simulation model.

\begin{tabular}{|l|l|l|l|l|}
\hline \multicolumn{1}{|c|}{ Variable } & MSE & $\mathbf{U}^{\mathbf{M}}$ & $\mathbf{U}^{\mathbf{S}}$ & $\mathbf{U}^{\mathbf{C}}$ \\
\hline Implemented rooftop solar panel & 0.02 & 0.18 & 0.31 & 0.51 \\
Accumulated customers & 0.003 & 0.20 & 0.12 & 0.68 \\
\hline
\end{tabular}

Table 4. Proposed simulation scenarios for analysing value creation of SMEs in the electricity sector.

\begin{tabular}{|l|l|}
\hline & \multicolumn{1}{c|}{ Characteristics } \\
\hline Scenario 1 & $\begin{array}{l}\text { This scenario assumes that the time to implement rooftop solar panel suffer delays, which affect the } \\
\text { service quality of SMEs as well as customer perception. This situation affects the brand identity ratio. }\end{array}$ \\
\hline Scenario 2 & $\begin{array}{l}\text { This scenario represents a marketing policy aims to invest on brand identity, while limiting others } \\
\text { resources used for the implementation of rooftop solar panel. }\end{array}$ \\
\hline Scenario 3 & $\begin{array}{l}\text { This scenario shows a policy aims to improve the implementation of rooftop solar panel in household, } \\
\text { but with insufficient investment on the brand identity of SMEs. }\end{array}$ \\
\hline Scenario 4 & $\begin{array}{l}\text { This scenario assumes coordination between SMEs resources, time to implemented rooftop solar } \\
\text { panel and brand identity ratio. }\end{array}$ \\
\hline
\end{tabular}


levels of creating value, while scenario 4 is quite the opposite.

Figure 5 shows the behaviour of the perceived customer value for the proposed scenarios. These results show how an increase in the brand identity through investment positively impacts on the perceived customer value (scenario 4 ), while that the lack of development and financial resources affect the customer value (scenario 1 to 3 ). Although the electricity market is one of considerable size, it warrants greater marketing attention. In this sense, value creation plays an important role in SMEs of the electricity sector.

Figure 6 presents the behaviour of accumulated brand identity between 2018 and 2030. The accumulation of brand identity exhibits effects of SMEs resources

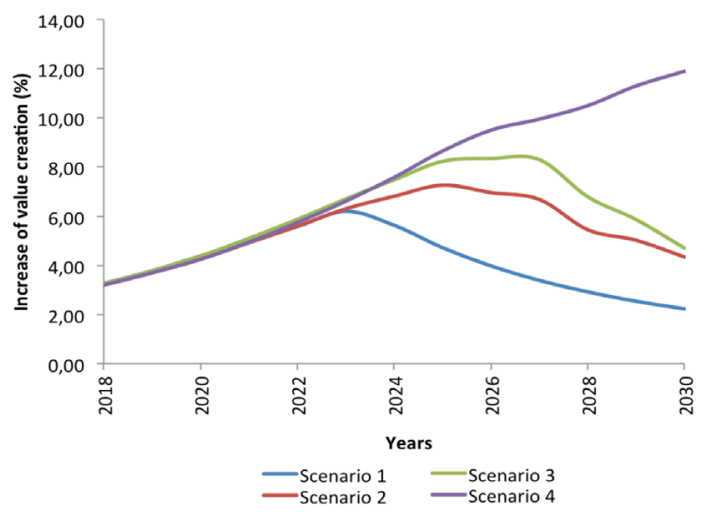

Figure 5. Behaviour of increase of value creation in SMEs of electricity sector.

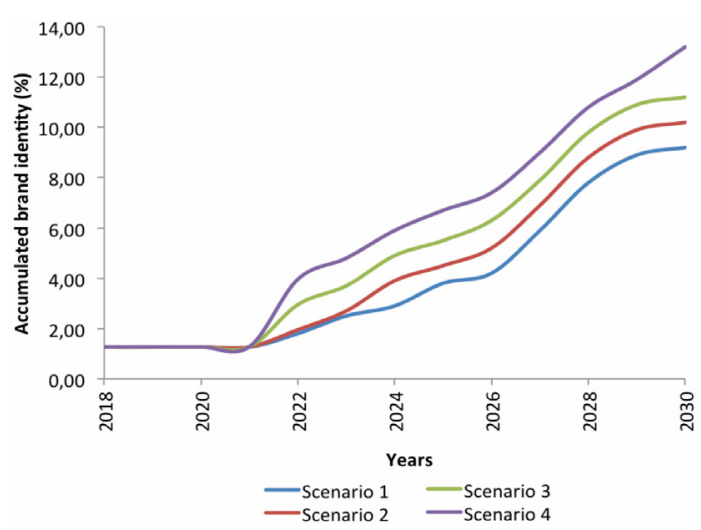

Figure 6. Effects of accumulated brand identity due to changes in implemented rooftop solar panel. due to improvement in terms of times of implemented rooftop solar panel of households. The scenarios 1, 2 and 3 suffer an increase of $8 \%$ between 2018 and 2030, while scenario 4 reaches an increase of $12 \%$ in this same period. This involves that the used resources and implemented time of solar panel may be related to brand identity of SMEs and therefore profit margin could be affected.

The discrepancy between desired and actual resources can cause drawbacks on actors along with the SMEs, such as shortages and surplus. Figures 7 (a) and (b) show the discrepancy of the SMEs resources (strategic resources) concerning desired resources (capacity). The length delays created situation to implement solar panel and insufficient brand identity. This comparison between scenarios suggests the need for marketing policies, especially for the

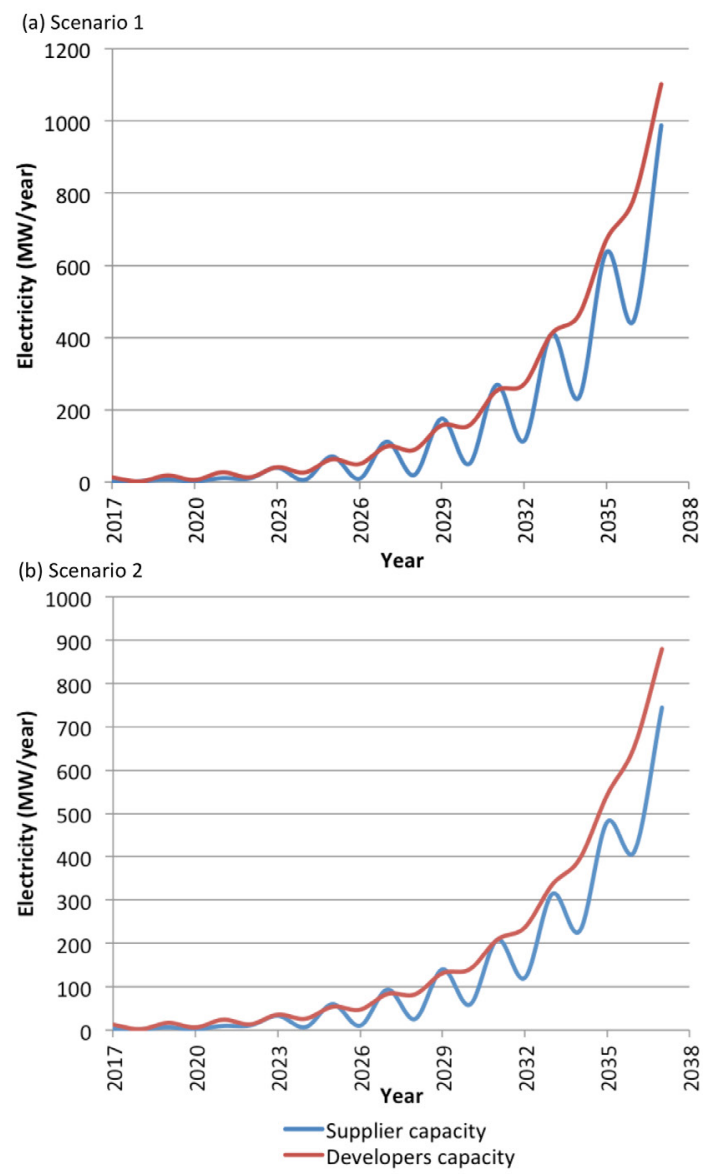

Figure 7. Discrepancy of the SMEs resources for the scenarios 1 and 2. 
second scenario that presents the higher discrepancy among the SMEs resources. Other experience like in Taiwan and Germany show that the coordination among key SMEs players provides advantages in the household sector [74]. In the case of Colombia, the adoption of photovoltaic power depends on a suitable diffusion policy [45], which contemplates the coordination used of resources among actors.

Figure 8 shows two scenarios with synchronisation for the variable of SMEs resources. It is occurred due to minimising the time of implementation of solar panel in the household. Scenarios 3 and 4 exhibit that the delays between adjustment time and their effects on resources generate a surplus in the supplier's inventory, while the developers inventory present shortages regarding desired resources. This situation required a major capacity of response of SMEs to changes in the brand identity. In this case,

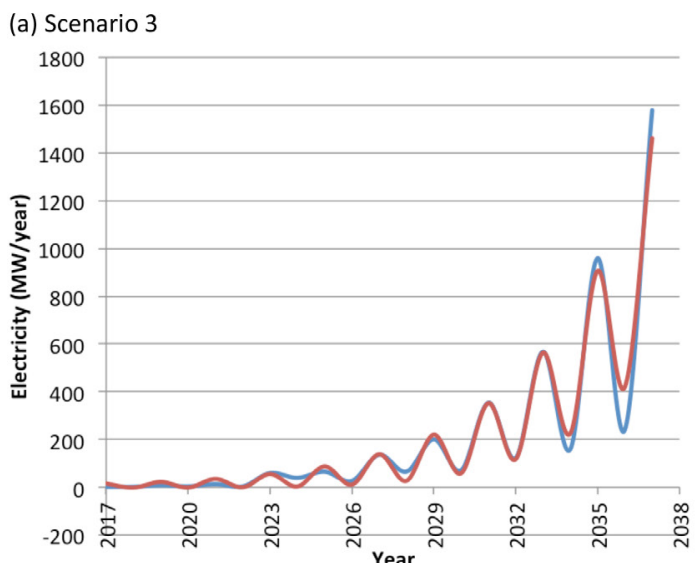

(b) Scenario 4

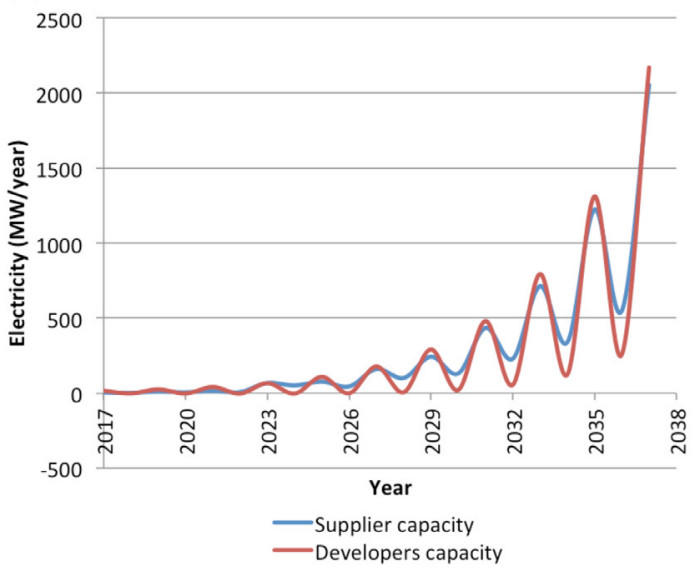

Figure 8. Synchronisation of the SMEs resources for the scenarios 3 and 4. the simulation model provides a better response to changes in resources for scenario 4.

In summary, scenarios 1, 2 and 3 have a response time higher than for scenario 4 , which could affect SMEs' behaviour. Thus, the impact on resources could be affected by the lower value creation and profits margin.

\section{CONCLUSION AND POLICY IMPLICATIONS}

Given the challenges and opportunities renewable energy market in Latin America for SMEs [38, 75], this paper considers a simulation modelling approach for better understanding the dynamics of the utility industry from brand identity and its effect on value creation. This modelling approach is also helpful for assessing alternatives marketing based on non-conventional renewable energy that may foster innovation and performance improvement in SMEs of the electricity sector. Also, it provides a model-based framework for analysing intangible resources of SMEs and offers guidance for designing alternative sustainable policy formulations. The research has also exhibited the need to adopt dynamic performance management (DPM) for the development of the brand identity of SMEs.

The promotion of renewable energy depends upon stakeholders' understanding of its profit and value [58]. The investment return marketing should be measured in terms of an expected change in the value of the customer that occurs from marketing strategies intervention [76]. Thus, customer value is an element that should be more studied in the marketing literature and applied to different areas to improve the relationships among the stakeholders in SMEs. Then, the energy providers should focus on product differentiation and value-added services [5].

The dynamic performance analysis indicates that brand identity derived from accumulation is one of the explications for value creation in SMEs. Changes in brand identity ratio, such as valueadded services or product differentiation, played an important role in the value creation process for SMEs in the electricity sector.

The long-term projection of the increase of value creation is obtained by applying these changes in 
the simulation model. Thus, a similar strategy could be used to analyse other marketing policies, using the simulation approach proposed here.

According to the simulation results, identity can influence consumer and increase demand for SMEs in the electricity sector. It is also suggested to managers to promote value-added services that improve the use of resources of the SMEs. Thus, a deeper understanding of green electricity marketing and consumer within the residential sector is crucial $[20,34]$.

Recently, renewable energy market has shown significant growth that has contributed to the competitiveness of the Latin American countries [77]. The study of the SMEs of photovoltaic power in Colombia may offer insights for managers and policymakers in terms of marketing policy design.

From the above, it is established that photovoltaic power is an alternative to generating sustainable energy for the country, but barriers related to policy, innovation and market do not allow the same diffusion. In this context, the modelling of the value chain of SMEs in the electricity sector allows understanding the energy system from the relationships identified between resources and policy to foster product differentiation and value-added services, including customer value generation.

Concerning the electricity market, differentiation has its foundations in the production method [34]. However, customer perception plays an important role in the development of green electricity marketing. In this sense, stimulating the use of non-conventional renewable energy could be an opportunity and challenge for the services sector of the electricity market.

\section{REFERENCES}

[1] V. de Gooyert, E. Rouwette, H. van Kranenburg and E. Freeman. "Reviewing the role of stakeholders in Operational Research: A stakeholder theory perspective". European Journal of Operational Research. Vol. 262 $\mathrm{N}^{\circ}$ 2, pp. 402-410.2017. ISSN: 0377-2217. DOI: 10.1016/j.ejor.2017.03.079.

[2] S. Matos and B. Silvestre. "Managing stakeholder relations when developing sustainable business models: The case of the Brazilian energy sector". Journal of Cleaner Production. Vol. 45, pp. 61-73. 2013. DOI:10.1016/j.jclepro.2012.04.023.

[3] V. Kumar, Z. Rahman and A.A. Kazmi. "Assessing the Influence of stakeholders on sustainability marketing strategy of indian companies". SAGE Open. Vol. 6 N $^{\circ} 3.2016$. DOI:10.1177/2158244016667991.

[4] C. Silveira, C. Lages and C. Simões. "Reconceptualizing brand identity in a dynamic environment". Journal of Business Research.Vol. $66 \mathrm{~N}^{\circ}$ 1, pp. 28-36. 2013. DOI:10.1016/j. jbusres.2011.07.020.

[5] A. Paladino and A. Pandit . "Competing on service and branding in the renewable electricity sector". Energy Policy. Vol. 45, pp. 378-388. 2012. DOI:10.1016/j.enpol.2012.02.046.

[6] P. Kotler". Customer value management". Journal of Creating Value. Vol. $3 \mathrm{~N}^{\mathrm{o}} 2$, pp. 170172. 2017. DOI:10.1177/2394964317706879.

[7] W. Ulaga. "Measuring customer-perceived value in business markets: An agenda for inquirí”. Industrial Marketing Management. Vol. $30 \mathrm{~N}^{\mathrm{o}}$ 4, pp. 315-319. 2001. DOI:10.1016/j. ijresmar.2017.10.001.

[8] T. Matherly, Z.G. Arens and T.J. Arnold. "Big brands, big cities: how the population penalty affects common, identity relevant brands in densely populated áreas". International Journal of Research in Marketing. Vol. $35 \mathrm{~N}^{\circ}$ 1, pp. 15-33. 2018. DOI:10.1016/j.ijresmar.2017.10.001.

[9] C. Xu, D. Peak and V. Prybutok. "A customer value, satisfaction, and loyalty perspective of mobile application recommendations". Decision Support Systems. Vol. 79, pp. 171183. 2015. ISSN 0167-9236. DOI:10.1016/j. dss.2015.08.008.

[10] V. Kumar and W. Reinartz. "Creating Enduring Customer Value". Journal of Marketing. Vol. 80 No6, pp. 36-68. 2016. DOI:10.1509/jm.15.0414.

[11] H. Butz, L. Goodstein and F. Edsel. "Gaining the Strategic Advantage". Vol. 1197, pp. 32137. 2001.

[12] S. Khalifa. "Customer value: a review of recent literature and an integrative configuration". Vol. $42 \mathrm{~N}^{\circ}$ 5. 2004. DOI:10.1108/002517404 10538497.

[13] H. Zhang, X. Liang and S.Wang. "Customer value anticipation, product innovativeness, and customer lifetime value: The moderating role 
of advertising strategy". Journal of Business Research. Vol. 69 N 9, pp. 3725-3730. 2016. DOI:10.1016/j.jbusres.2015. 09.018.

[14] J. Kishimoto, M. Goto and K. Inoue. "Do acquisitions by electric utility companies create value? Evidence from deregulated markets". Energy Policy. Vol. 105, pp. 212224. 2017. DOI:10.1016/j.enpol.2017.02.032.

[15] M.J. Lovett, R. Peres and R. Shachar. "On brands and word of mouth". Journal of Marketing Research. Vol. 50, pp. 427-44. 2013. DOI:10.1509/jmr.11.0458.

[16] H. Oh and K. Kim. "Customer satisfaction, service quality, and customer value: years 2000-2015". International Journal Contemporany Hospitaly Management. Vol. $29 \mathrm{~N}^{\mathrm{o}}$ 1, pp. 2-29. 2017. DOI:10.1108/ IJCHM-10-2015-0594.

[17] S. Leroi-Werelds, S. Streukens, M. Brady and G .Swinnen. "Assessing the value of commonly used methods for measuring customer value: A multi-setting empirical study". Journal of the Academy Marketing Science.Vol. 42, pp. 430-451. 2014. DOI:10.1007/s11747-013-0363-4.

[18] M. Wouters and M.Kirchberger. "Customer value propositions as interorganizational management accounting to support customer collaboration". Industrial Marketing Management. Vol. 46, pp. 54-67. 2015. DOI:10.1016/j.indmarman.2015.01.005.

[19] UPME. "Integración de las energías renovables no convencionales en Colombia". 2015.

[20] L. Cardenas, M. Zapata, CJ. Franco and I. Dyner. "Assessing the combined effect of the diffusion of solar rooftop generation, energy conservation and efficient appliances in households". Journal of Cleaner Production. Vol. 162, pp. 491-503. 2017. DOI:10.1016/j. jclepro.2017.06.068.

[21] L.M. Cardenas, C.J.Franco and I. Dyner. "Assessing emissions-mitigation energy policy under integrated supply and demand analysis: The Colombian case". Journal of Cleaner Production. Vol. 112, pp. 3759-3773. 2016. DOI:10.1016/j.jclepro.2015.08.089.

[22] A. Bradshaw. "Regulatory change and innovation in Latin America: The case of renewable energy in Brazil". Utilities Policy. Vol. 49, pp. 156-164. 2017. DOI:10.1016/j. jup.2017.01.006.
[23] M.M. Herrera, A. Guerrero and C .Sandoval. "A review of the photovoltaic supply chain in Latin America: challenges and opportunities". Revista VirtualPro. 2018.

[24] R. Santos. "International power market impact for Latin America". 2016.

[25] J.D. Sterman. "Business dynamics: Systems Thinking and Modeling for a Complex World". McGraw-Hill. 2000.

[26] N. Ghaffarzadegan, J. Lyneis and G.P. Richardson. "How small system dynamics models can help the public policy process". System Dynamics Review. Vol. 27, pp. 22-44. 2011. DOI: $10.1002 / \mathrm{sdr} .442$.

[27] E. Moxnes and P.I. Davidsen. "Intuitive understanding of steady-state and transient behaviors". System Dynamics Review. Vol. 32, pp. 128-153. 2016. DOI:10.1002/sdr.1561.

[28] J.D. Morcillo, C.J. Franco and F. Angulo. "Delays in electricity market models". Energy Strategy Reviews. Vol. 16, pp. 24-32. 2017. DOI: 10.1016/j.esr.2017.02.004.

[29] I. Buil, S. Catalán and E. Martínez. "The importance of corporate brand identity in business management: An application to the UK banking sector". BRQ Business Research Quarterly. Vol. 19, pp. 3-12. 2016. DOI: $10.1016 /$ j.brq.2014.11.001.

[30] J. Kapferer. "The new strategic brand management: creating and sustaining brand equity long term. Kogan Page. Fourth edition. 2008.

[31] D. Coleman, L. de Chernatony and G. Christodoulides. "B2B service brand identity: Scale development and validation". Industrial Marketing Management. Vol. 40, pp. 1063-1071. 2011. DOI: 10.1016/j. indmarman.2011.09.010.

[32] L. de Chernatony. "From brand vision to brand evaluation". Butterworth-Heinemann. 2010.

[33] D. Aaker. "Building strong brands". New York: The Free Press. 1996.

[34] R. Hanimann, J. Vinterbäck and C. MarkHerbert. "Consumer behavior in renewable electricity: Can branding in accordance with identity signaling increase demand for renewable electricity and strengthen supplier brands?". Energy Policy. Vol. 78, pp. 11-21. 2015. DOI: 10.1016/j.enpol.2014.12.010.

[35] P. Jayapal and A. Omar. "The Role of Value Co-Creation on Brand Image. Digit. Mark. 
Consum”. Engagem, IGI Global, pp. 326348. 2017. DOI:10.4018/978-1-5225-5187-4. ch017.

[36] Bayer B. "Experience with auctions for wind power in Brazil". Renewable and Sustainable Energy Reviews. Vol. 81, pp. 2644-2658. 2018. DOI:10.1016/j.rser.2017.06.070.

[37] M.M. Zuluaga and I. Dyner "Incentives for renewable energy in reformed LatinAmerican electricity markets: the Colombian case". Journal of Cleaner Production. Vol. 15, pp. 153-162. 2007. DOI:10.1016/j. jclepro.2005.12.014.

[38] P.Y. Gan and Z.D. Li. Quantitative study on long term global solar photovoltaic market. Renewable and Sustainable Energy Reviews. Vol. 46, pp. 88-99. 2015. DOI:10.1016/j. rser.2015.02.041.

[39] G. Simpson and J. Clifton. "Testing diffusion of innovations theory with data: financial incentives, early adopters, and distributed solar energy in Australia". Energy Research Social Science. Vol. 29, pp. 12-22. 2017. DOI: 10.1016/j.erss.2017.04.005.

[40] A.A. Radomes and S. Arango. "Renewable energy technology diffusion: An analysis of photovoltaic-system support schemes in Medellín, Colombia”. Journal of Cleaner Production. Vol. 92, pp. 152-161. 2015. DOI: 10.1016/j.jclepro.2014.12.090.

[41] E.J. Pérez and J. Del Valle. "Prospects for photovoltaics in Latin America: The Mexican case”. Solar Cells Vol. 6, pp. 281-293. 1982. DOI: 10.1016/0379-6787(82)90035-7.

[42] J. Silveira, C. Tuna and W. Lamas. "The need of subsidy for the implementation of photovoltaic solar energy as supporting of decentralized electrical power generation in Brazil". Renewable and Sustainable Energy Reviews. Vol. 20, pp. 133-141. 2013. DOI:10.1016/j.rser.2012.11.054.

[43] K.H. Solangi, M.R Islam, R. Saidur, NA, Rahim and H. Fayaz. "A review on global solar energy policy". Renewable and Sustainable Energy Reviews. Vol. 15, pp. 2149-2163. 2011. DOI: 10.1016/j.rser.2011.01.007.

[44] S. Postic, S. Selosse and N.Maïzi. "Energy contribution to Latin American INDCs: analyzing sub-regional trends with a TIMES model". Energy Policy. Vol. 101, pp. 170-184. 2017. DOI: 10.1016/j.enpol.2016.11.023.
[45] M. Jimenez, C.J. Franco and I. Dyner. "Diffusion of renewable energy technologies: The need for policy in Colombia". Energy. Vol. 111, pp. 818-829. 2016. DOI:10.1016/j. energy.2016.06.051.

[46] S. Arendt and M. Brettel. "Understanding the influence of corporate social responsibility on corporate identity, image, and firm performance". Management Decision. Vol. 48, pp. 1469-1492. 2010. DOI: 10.1108/00251741011090289.

[47] F. Cosenz. "A dynamic viewpoint to design performance management systems in academic institutions: Theory and practice". International Journal of Public Administration. Vol. 37, pp. 955-969. 2014. DOI:10.1080/0 1900692.2014.952824.

[48] C. Bianchi. "System dynamics for performance management". Springer International Publishing. Vol. 49. 2016. Zurich, Switzerland.

[49] A. Parasuraman and D. Grewal. "The impact of technology on the quality-value-loyalty chain: A research agenda". Journal of the Academy of Marketing Science. Vol. 28. 2000. DOI:10.1177/0092070300281015.

[50] J.L. Aaker, E. N. Garbinsky and K. D. Vohs. "Cultivating admiration in brands: Warmth, competence, and landing in the golden quadrant". Journal Consumer Psychology. Vol. 22, pp. 191-194. 2012. DOI:10.1016/j. jcps.2011.11.012.

[51] S. Fournier and C. Alvarez. " Brands as relationship partners: Warmth, competence, and in-between". Journal Consumer Psychology. Vol. 22, pp. 177-185. 2012. DOI:10.1016/j.jcps.2011.10.003.

[52] K.L. Keller. "Understanding the richness of brand relationships: Research dialogue on brands as intentional agents". Journal Consumer Psychology. Vol. 22, pp. 186-190. 2012. DOI:10.1016/j.jcps.2011.11.011.

[53] H. Kapoor and L. A. Heslop. "Brand positivity and competitive effects on the evaluation of brand extensions". International Journal of Research in Marketing. Vol. 26, pp. 228-37. 2009. DOI:10.1016/j.ijresmar.2009.05.001.

[54] P. Foroudi, Z. Jin, S. Gupta, M.M. Foroudi and P.J. Kitchen. "Perceptional components of brand equity: Configuring the Symmetrical and Asymmetrical Paths to brand loyalty and brand purchase 
intention”. Journal of Business Research. Vol. 89, pp. 462-474. 2018. DOI:10.1016/j. jbusres.2018.01.031.

[55] J. Berendt, S. Uhrich and S. A. Thompson. "Marketing, get ready to rumble-How rivalry promotes distinctiveness for brands and consumers". Journal of Business Research. Vol. 88, pp. 161-172. DOI:10.1016/j. jbusres.2018.03.015.

[56] O. Topaloglu and O.N. Gokalp. "How brand concept affects consumer response to product recalls: A longitudinal study in the U.S. auto industry". Journal of Business Research. Vol. 88, pp. 245-254. 2018. DOI: 10.1016/j. jbusres.2018.03.035.

[57] F. Eggers, M. O’Dwyer, S. Kraus, C. Vallaster and S. Güldenberg. "The impact of brand authenticity on brand trust and SME growth: A CEO perspective". Journal of World Business Vol. 48, pp. 340-348. 2013.DOI: 10.1016/j.jwb.2012.07.018.

[58] H-M. Wee, W-H. Yang, C-W. Chou and V. Padilan. "Renewable energy supply chains, performance, application barriers, and strategies for further development". Renewable and Sustain Energy Revews. Vol. 16, pp. 5451-5465. 2012. DOI:10.1016/j. rser.2012.06.006.

[59] C.M. Jardon. "Location and competitiveness in subsistence small businesses". Competitiveness Review. Vol. 28, pp. 155171. 2018. DOI:10.1108/CR-11-2016-0075.

[60] C. Bianchi, F. Cosenz and M. Marinković. "Designing dynamic performance management systems to foster SME competitiveness according to a sustainable development perspective: empirical evidences from a case-study". International Jounal of Business Performance Management. Vol. 16, pp. 84-108. 2015. DOI:10.1504/ IJBPM.2015.066042.

[61] S. Ahmad, R. Mat Tahar, F. MuhammadSukki, AB. Munir and R. Abdul Rahim. "Application of system dynamics approach in electricity sector modelling: A review". Renewable and Sustainable Energy Reviews. Vol. 56, pp. 29-37. 2016. DOI:10.1016/j. rser.2015.11.034.

[62] J.W. Forrester. "Industrial dynamics". Journal of the Operational Research Society. Vol. 48, pp. 1037-1041. 1997.
[63] D. Ford and J. Sterman. "Dynamic modelling of product development processes". System Dynamics Review. Vol. 14, pp. 31-68. 1998. DOI: 10.1002/(SICI)1099-1727 (199821)14:1<31::AID-SDR141>3.0.CO;2-5.

[64] M. Herrera, I. Dyner and F. Cosenz. "Alternative Energy Policy for Mitigating the Asynchrony of the Wind-Power Industry's Supply Chain in Brazil"'. Innovative Solutions for Sustainable .Supply Chain. Cham: Springer International Publishing, pp. 199-221. 2018. DOI:10.1007/978-3-319-94322-0_8.

[65] H. Qudrat-Ullah. "The Physics of Stocks and Flows of Energy Systems Applications in Energy Policy". Springer London. 2016.

[66] S. Lee, Y. Geum, H. Lee and Y. Park. "Dynamic and multidimensional measurement of product-service system (PSS) sustainability: A triple bottom line (TBL)-based system dynamics approach". Journal of Cleaner Production. Vol. 32, pp. 173-182. 2012. DOI:10.1016/j.jclepro.2012.03.032.

[67] I.J. Martinez-Moyano and G.P.Richardson "Best practices in system dynamics modeling". System Dynamics Review. Vol. $29 \mathrm{~N}^{\circ} 2$, pp. 102-123. 2013. DOI:10.1002/sdr.1495.

[68] Y. Barlas. "Formal aspects of model validity and validation in system dynamics". System Dynamics Review. Vol. 12, pp. 183-210. 1996. DOI: 10.1002/(SICI)1099-1727 (199623).

[69] J. Sterman. "Appropriate summary statistics for evaluating the historical fit of system dynamics models. Dynamica. Vol. 10, pp. 51-66. 1984.

[70] R. Oliva. " Model calibration as a testing strategy for system dynamics models". European Journal of Operational Research. Vol. 151, pp. 552-568. 2003. DOI:10.1016/ S0377-2217(02)00622-7.

[71] UPME. "Informe mensual de variables de generación y del mercado eléctrico Colombiano - Marzo de 2017 Subdirección de Energía Eléctrica-Grupo de Generación", pp. 1-16. 2017. http://www.siel.gov.co/ portals/0/generacion/2017/Informe_de_ variables_Mar_2017.pdf.

[72] B. Bala, F. Arshad and K. Noh. "System dynamics: Modelling and simulation". Springer Singapore. 2017. DOI:10.1007/ SpringerReference_7284. 
[73] I. Dyner. "Energy modelling platforms for policy and strategy support". The Journal of the Operational Research Society. Vol. $51 \mathrm{~N}^{\circ} 2$, pp. 136-144. 2000. DOI:10.2307/254253.

[74] F. Jia, H. Sun and L. Koh. "Global solar photovoltaic industry: an overview and national competitiveness of Taiwan". Journal of Cleaner Production. Vol. 126, pp. 550-562. 2016. DOI:10.1016/j.jclepro.2016.03.068.

[75] B. Sahu. "A study on global solar PV energy developments and policies with special focus on the top ten solar PV power producing countries". Renewable and Sustainable Energy Reviews. Vol. 43, pp. 621-634. 2015. DOI:10.1016/j.rser.2014.11.058.

[76] M. Braun, D. Schweidel and E. Stein. "Transaction attributes and customer valuation". Journal of Marketing Research. Vol. $52 \mathrm{~N}^{\circ}$ 3, pp. 848-864. 2015.DOI:10.1509/ jmr.13.0377.

[77] M. Herrera, I. Dyner and F. Cosenz. "Effects of the penetration of wind power in the Brazilian electricity market". Revista Ingenieria Industrial. Vol. 15 No 3, pp. 309-319. 2017. 